\author{
WILLIAM H. BRANSON
}

Princeton University

\title{
U.S. Comparative Advantage: Some Further Results
}

IN THE LAST ISSUE OF this journal, Helen Junz and I reported the preliminary results of an analysis of the sources of U.S. comparative advantage in trade in manufactured goods. The basic answer was that the U.S. advantage is in commodities whose production uses human capital intensively. ${ }^{1}$ We looked only at data for the mid-1960s, which were developed separately by Keesing and Hufbauer. ${ }^{2}$ To study the data, we performed multiple regressions relating net exports by standard international trade classification (SITC) commodity groups to six production characteristics: human capital per man $(H)$, physical capital per man $(K)$, a measure of the presence of economies of scale in production $(S)$, the date at which the commodity first appeared in the U.S. export schedule $(P)$, the ratio of expenditures on research and development to value added $(R D)$, and the

1. See William H. Branson and Helen B. Junz, "Trends in U.S. Trade and Comparative Advantage," Brookings Papers on Economic Activity (2:1971), pp. 285-338.

2. Donald B. Keesing, "The Impact of Research and Development on United States Trade," Journal of Political Economy, Vol. 75 (February 1967), pp. 38-48; G. C. Hufbauer, "The Impact of National Characteristics and Technology on the Commodity Composition of Trade in Manufactured Goods," in Raymond Vernon (ed.), The Technology Factor in International Trade, A Conference of the Universities-National Bureau Committee for Economic Research (Columbia University Press for the National Bureau of Economic Research, 1970). 
fraction of employees in the professional, scientific, and technical categories $(T) .^{3}$

While the earlier results showed fairly clearly the positive relation of net exports to human capital per man and their negative relation to physical capital per man, several discussants suggested that the analysis would be improved if the dependent variable in the regressions were scaled to reflect size of industry. The point is that large industries, all other things equal, are likely to have larger trade surpluses or deficits than small industries. For example, consider a large industry producing commodity $A$ and a small industry producing commodity $B$, both with exactly the same set of production characteristics. The United States might export $\$ 12$ billion and import $\$ 10$ billion of good $A$ for a $\$ 2$ billion surplus, while if industry $B$ is one-tenth the size of $A$, the United States would export $\$ 1.2$ billion and import $\$ 1.0$ billion of $B$, for a $\$ 200$ million surplus. The earlier estimates would be inefficient in that they include no variable that reflects this difference in scale.

Several ways to remedy this deficiency have been suggested. One that could be applied with the data already in hand is to use as the dependent variable the ratio of exports to gross trade (exports plus imports) by industry. In the example above, this would give a ratio of exports to gross trade of $0.545(=12 / 22=1.2 / 2.2)$ for both commodities. This measure is thus scale free, varying between zero and unity, and should improve the estimates.

\section{Human-capital Intensiveness of U.S. Exports}

The new estimates are shown in Table 1. Parts A, B, and C of that table correspond to Tables 9, 10, and 11 in the earlier paper. In each case I have reproduced the first equation of the earlier table, then reestimated the equation replacing net exports $(X)$ with the ratio of exports to gross trade $(X R)$, and then provided another equation or two to sharpen the results.

3. All of these measures are taken directly from Hufbauer and Keesing except one, the human capital measure. This is calculated by subtracting the median income in 1964 for a worker 25 years old and over with less than an eighth-grade education, $\$ 1,717$, from Hufbauer's average wage per industry, and then capitalizing this difference at a 10 percent rate of return. The median income is the weighted average for males and females from U.S. Bureau of the Census, Current Population Reports, Series P-60, No. 47, "Income in 1964 of Families and Persons in the United States" (1965), p. 39. 
Table 1. Regressions Explaining Net Exports of Manufactured Goods, by SITC Commodity Groups, 1964

\begin{tabular}{|c|c|c|c|c|c|c|c|c|c|}
\hline \multirow{2}{*}{$\begin{array}{c}\text { Equa- } \\
\text { tion } \\
\end{array}$} & \multirow{2}{*}{$\begin{array}{c}\text { Dependent } \\
\text { variable }\end{array}$} & \multicolumn{6}{|c|}{ Coefficients of independent variables } & \multicolumn{2}{|c|}{$\begin{array}{c}\text { Summary } \\
\text { statistics }\end{array}$} \\
\hline & & $K$ & $H$ & $S$ & $P$ & $R D$ & $T$ & $R^{2}$ & $F$ \\
\hline \multicolumn{10}{|c|}{ A. Regressions on 101 three-digit commodity groups } \\
\hline$(1-1)$ & $X(64)$ & $\begin{array}{c}-8.63 \\
(2.7)\end{array}$ & $\begin{array}{c}8.18 \\
(3.1)\end{array}$ & $\begin{array}{c}3.44 \\
(1.3)\end{array}$ & $\begin{array}{l}9.22 \\
(2.3)\end{array}$ & .. & .. & 0.21 & 6.65 \\
\hline$(1-2)$ & $X R(64)$ & $\begin{array}{r}-1.08 \\
(3.2)\end{array}$ & $\begin{array}{c}1.18 \\
(4.3)\end{array}$ & $\begin{array}{c}0.25 \\
(0.9)\end{array}$ & $\begin{array}{c}0.90 \\
(2.1)\end{array}$ & $\ldots$ & $\cdots$ & 0.26 & 8.43 \\
\hline$(1-3)$ & $X R(64)$ & $\begin{array}{r}-1.20 \\
(3.8)\end{array}$ & $\begin{array}{c}1.37 \\
(5.2)\end{array}$ & $\ldots$ & $\cdots$ & $\ldots$ & $\cdots$ & 0.22 & 13.96 \\
\hline \multicolumn{10}{|c|}{ B. Regressions on 61 three-digit commodity groups } \\
\hline$(1-4)$ & $X(64)$ & $\begin{array}{c}-9.92 \\
(2.5)\end{array}$ & $\begin{array}{r}8.47 \\
(1.7)\end{array}$ & $\begin{array}{l}2.24 \\
(2.6)\end{array}$ & $\begin{array}{l}17.21 \\
(1.9)\end{array}$ & .. & .. & 0.29 & 5.72 \\
\hline$(1-5)$ & $X R(64)$ & $\begin{array}{r}-1.22 \\
(3.1)\end{array}$ & $\begin{array}{l}1.08 \\
(2.2)\end{array}$ & $\begin{array}{c}0.60 \\
(1.6)\end{array}$ & $\begin{array}{c}0.52 \\
(0.8)\end{array}$ & ... & .. & 0.24 & 4.50 \\
\hline$(1-6)$ & $X R(64)$ & $\begin{array}{r}-1.14 \\
(2.9)\end{array}$ & $\begin{array}{c}0.92 \\
(1.9)\end{array}$ & $\begin{array}{c}0.44 \\
(1.1)\end{array}$ & $\begin{array}{c}0.43 \\
(0.7)\end{array}$ & $\begin{array}{l}1.34 \\
(1.6)\end{array}$ & $\ldots$ & 0.27 & 4.15 \\
\hline$(1-7)$ & $X R(64)$ & $\begin{array}{r}-1.25 \\
(3.2)\end{array}$ & $\begin{array}{l}1.01 \\
(2.2)\end{array}$ & $\ldots$ & $\ldots$ & $\begin{array}{l}1.61 \\
(2.0)\end{array}$ & $\ldots$ & 0.25 & 6.45 \\
\hline$(1-8)$ & $X(64)$ & $\begin{array}{r}-10.47 \\
(2.6)\end{array}$ & $\begin{array}{c}9.28 \\
(1.9)\end{array}$ & $\ldots$ & $\ldots$ & $\begin{array}{l}25.15 \\
(3.1)\end{array}$ & $\ldots$ & 0.28 & 7.39 \\
\hline \multicolumn{10}{|c|}{ C. Regressions on 28 two-digit commodity groups } \\
\hline$(1-9)$ & $X(64)$ & $\begin{array}{r}-55.71 \\
(2.4)\end{array}$ & $\begin{array}{l}39.01 \\
(2.1)\end{array}$ & $\begin{array}{l}27.52 \\
(1.0)\end{array}$ & $\begin{array}{l}28.96 \\
(1.1)\end{array}$ & $\ldots$ & $\ldots$ & 0.33 & 3.00 \\
\hline$(1-10)$ & $X R(64)$ & $\begin{array}{c}-0.60 \\
(1.1)\end{array}$ & $\begin{array}{l}1.50 \\
(3.4)\end{array}$ & $\begin{array}{c}0.49 \\
(0.8)\end{array}$ & $\begin{array}{c}0.79 \\
(1.2)\end{array}$ & $\ldots$ & $\ldots$ & 0.56 & 7.64 \\
\hline$(1-11)$ & $X R(64)$ & $\begin{array}{c}-0.71 \\
(1.3)\end{array}$ & $\begin{array}{l}1.77 \\
(4.5)\end{array}$ & $\ldots$ & $\ldots$ & $\ldots$ & $\ldots$ & 0.52 & 14.1 \\
\hline$(1-12)$ & $X R(64)$ & $\begin{array}{r}-0.84 \\
(1.9)\end{array}$ & $\begin{array}{c}1.08 \\
(3.0)\end{array}$ & $\ldots$ & $\ldots$ & $\ldots$ & $\begin{array}{r}2.37 \\
(4.0)\end{array}$ & 0.71 & 22.0 \\
\hline$(1-13)$ & $X(64)$ & $\begin{array}{c}-61.74 \\
(2.6)\end{array}$ & $\begin{array}{l}42.85 \\
(2.2)\end{array}$ & $\ldots$ & $\ldots$ & $\ldots$ & $\begin{array}{l}25.74 \\
(0.8)\end{array}$ & 0.30 & 3.57 \\
\hline
\end{tabular}

a. See Table 1a below for definitions, units, means, and sources.

Note: The numbers in parentheses are $t$-ratios.

In Part A of Table 1, the coefficients of the regressions on the full sample of 101 three-digit SITC commodities are reported. Replacing net exports by the scaled version improves the estimate and raises the significance of both the physical and human capital variables.

The earlier finding that U.S. exports are human-capital intensive, which 
Table 1a. Definitions, Units, and Means of Variables for Table 1

\begin{tabular}{|c|c|c|c|c|c|}
\hline \multirow[b]{2}{*}{ Variable } & \multirow[b]{2}{*}{ Definition } & \multirow[b]{2}{*}{ Unit } & \multicolumn{3}{|c|}{ Mean } \\
\hline & & & $\begin{array}{l}101 \\
\text { ob- } \\
\text { serva- } \\
\text { tions }\end{array}$ & $\begin{array}{c}61 \\
o b- \\
\text { serva- } \\
\text { tions }^{\mathrm{a}}\end{array}$ & $\begin{array}{c}28 \\
\text { ob- } \\
\text { serva- } \\
\text { tions }\end{array}$ \\
\hline$X(64)$ & Net exports in 1964 & Millions of dollars & 74.8 & 120.7 & 270.2 \\
\hline$(X R 64)$ & $\begin{array}{l}\text { Ratio of exports to exports } \\
\text { plus imports in } 1964\end{array}$ & Percent & 56.7 & 60.9 & 57.7 \\
\hline$K$ & Physical capital per man & Thousands of dollars & 12.2 & 15.7 & 12.2 \\
\hline$H$ & Human capital per man & Thousands of dollars & 42.7 & 47.6 & 41.3 \\
\hline$S$ & Scale economies measure & Percent & 3.1 & 3.6 & 4.2 \\
\hline$P$ & First trade date & Year & 1945.2 & 1945.5 & 1944.5 \\
\hline$R D$ & $\begin{array}{l}\text { Research and development } \\
\text { expenditures as fraction } \\
\text { of value added }\end{array}$ & Percent & $\ldots$ & 3.4 & $\cdots$ \\
\hline$T$ & $\begin{array}{l}\text { Professional, scientific, and } \\
\text { technical workers as } \\
\text { fraction of all employees }\end{array}$ & Percent & $\ldots$ & ... & 8.98 \\
\hline
\end{tabular}

Sources: Data on U.S. trade by SITC commodity groups are from Organisation for Economic Co. operation and Development, Trade by Commodities, Detailed Analysis by Products, Imports, 1964, Series C (OECD), and OECD, Trade by Commodities, Detailed Analysis by Products, Exports, 1964, Series C(OECD). Data on research and development expenditures are from Donald B. Keesing, "The Impact of Research and Development on United States Trade," Journal of Political Economy, Vol. 75 (February 1967), p. 47. All other data are from G. C. Hufbauer, "The Impact of National Characteristics and Technology on the Commodity Composition of Trade in Manufactured Goods," in Raymond Vernon (ed.), The Technology Factor in International Trade, A Conference of the Universities-National Bureau Committee for Economic Research (Columbia University Press for the National Bureau of Economic Research, 1970), Table A-2.

a. In Tables 9, 10, and 11 of William H. Branson and Helen B. Junz, "Trends in U.S, Trade and Comparative Advantage," Brookings Papers on Economic Activity (2:1971), the mean of the human capital variable was reported low by a factor of 10 : The mean is 43 , not 4.3 , for example. The human capital coefficients in Tables 9 and 10 were high by a factor of 10 : In equation (1-1), for example, the coefficient was reported as 81.82 instead of the correct 8.182 . Table 11 avoided this error. In addition, the means for the 101 -observation sample reported in Table 9 were also reported in Table 10 as the means for the 61-observation sample. Both of these errors are corrected in Table 1 here.

is consistent with numerous findings since Leontief's initial work, ${ }^{4}$ is strengthened by the revision. On the other hand, the significance of both "technological" variables-scale economies and the first trade date-is reduced. Thus the new estimates offer even stronger support for the validity of a basic three-factor view of trade in manufactured goods as opposed to a more complicated model with additional technological variables. In equation (1-3) the technological variables are dropped, and the physical

4. Wassily Leontief, "Domestic Production and Foreign Trade; the American Capital Position Re-examined," in Richard E. Caves and Harry G. Johnson, Selection Committee, Readings in International Economics, Vol. 11 (Richard D. Irwin for the American Economic Association, 1968). 
and human capital variables become more significant, with an increase in the significance of the entire regression, as measured by the $F$-statistic.

\section{The Role of Research and Development Expenditures}

Part B of Table 1 explores research and development expenditures (R\&D) as an explanation of variations in U.S. trade. Since the R\&D data published by Keesing cover only sixty-one of our observations, I first show the reestimated basic equation from Part A. Introducing the scaled version of the trade variable (equation 1-5) reduces the significance of the entire regression in the sixty-one-observation sample. On the other hand, scaling increases the significance of the $K$ and $H$ variables. Furthermore, a comparison of equation (1-5) with (1-2) makes apparent that reducing the sample size reduces the importance of the human capital variable substantially.

When the research and development variable $(R D)$ is added to the analysis in equations (1-6) and (1-7), its coefficient has the expected sign and is marginally significant. Thus R\&D expenditures may affect trade independently from their effect on human capital inputs into production.

Scaling the export variable reduces the significance of $R \& D$ expenditures, as can be seen by comparing equations (1-7) and (1-8). It reduces the $t$-ratio of $R D$ from 3.1 to 2.0 , a major drop in the significance of the variable. $^{5}$

\section{Human Capital and Skill Ratios}

In Part $\mathrm{C}$ of Table 1, the ratio of professional, scientific, and technical workers to total employees - the "skill ratio," $T$-is added to the analysis to see if it has explanatory power independent of its contribution to human capital. These data are available for only twenty-eight two-digit SITC commodities.

First, the results are blurred all around when the sample is reduced from 101 observations (equation 1-1) to 28 observations (equation 1-9). Aver-

5. The potential bias in not scaling the net export variables was not noted by Baldwin, who apparently used as his dependent variable $\left(X_{i} / \Sigma X_{i}\right)-\left(M_{i} / \Sigma M_{i}\right)$, where $X$ is exports and $M$ imports. If trade is roughly balanced, this boils down to $\left(X_{i}-M_{i}\right) / \Sigma X_{i}$, so that no scaling is involved; each industry's net exports are divided by the same number, total exports. See Robert E. Baldwin, "Determinants of the Commodity Structure of U.S. Trade," American Economic Review, Vol. 61 (March 1971), p. 133, note 22. 
aging the three-digit data into two-digit categories eliminates much of the independent variation observed at the disaggregated level. Introduction of the scaled version of the trade variable, in equation (1-10), raises the significance of the entire equation, as well as that of human capital, and lowers that of physical capital. This relation is observed also in equation (1-11), which eliminates the scale economies and first-trade-date variables.

In equation (1-12) the skill ratio is added to the analysis. It takes on a significant coefficient and reduces the importance of the human capital measure, which nevertheless remains quite significant. Thus it appears, at least in this twenty-eight-observation sample, that the fraction of employees in the professional, scientific, and technical categories contributes to the explanation of trade beyond its contribution to human capital. A comparison of equations (1-12) and (1-13) demonstrates that scaling the trade variable produced this new result. At this level of aggregation human capital and the skill ratio are quite significant and physical capital marginally so in explaining trade.

\section{Conclusion}

The introduction of a scaled version of the trade variable has generally improved the significance of the results and also strengthened the conclusion that exports by the United States are intensive in human capital while its imports are intensive in physical capital. The earlier impressions of the marginal importance of scale economies and the first trade date, as a proxy for the product cycle, are also confirmed.

The importance of research and development expenditures was probably overstated in the earlier results; here they contribute positively to the U.S. trade advantage but with less statistical significance.

The only real change from the earlier results is in the role of the skill ratio in explaining trade independently from its contribution to human capital. When the trade variable is scaled, the skill ratio becomes quite significant, while the human capital measure is also significant. ${ }^{6}$ But as we noted in the earlier paper, this result comes from a small sample of highly aggregated data; its importance remains to be confirmed by a much more careful study than this set of preliminary estimates.

6. This observation is in agreement with the intuition of the co-author of the earlier paper, Helen Junz, who felt all along that there was something wrong with the results concerning the skill ratio. 